\title{
Study on the Present Situation and Improvement Strategy of Work-integrated Learning in Higher Vocational Colleges
}

\author{
Liu Liying * (Corresponding Author) \\ College of Public Management \\ Tianjin Vocational Institute \\ Tianjin, China \\ liuliying0718@163.com \\ Bian Guofeng \\ College of Public Management \\ Tianjin Vocational Institute \\ Tianjin, China \\ 77856941@qq.com
}

\author{
Yang Renjie \\ College of Engineering and Technology \\ Tianjin Agricultural University \\ Tianjin, China \\ rjyang1978@163.com \\ Wang Shuwen \\ College of Public Management \\ Tianjin Vocational Institute \\ Tianjin, China \\ 739796426@qq.com
}

\begin{abstract}
The work-integrated learning is the basic way to cultivate applied talents in higher vocational colleges. It is the common need of the development of higher vocational education and the development of industry and enterprise. However, there are many problems in the implementation process of workintegrated learning model in higher vocational colleges. The purpose of this paper is to analyze the problems in the process of implementing work-integrated learning mode, mainly due to the deviation of educational theory, the disconnection between working and learning, and the imperfect operation mechanism. In this regard, this paper proposes improvement from the following five aspects: establishing a sound legal system of work integrated learning, establishing a special coordinating body system, building a training and training joint system, promoting system and mechanism innovation and mobilizing the enthusiasm of enterprises. Through the above measures, the work-integrated learning model can be implemented in order to train high quality talents for the society.
\end{abstract}

Keywords-Higher Vocational College, The Work-integrated Learning Model, The Cooperation of College and Enterprise, Problems and Strategies

\section{INTRODUCTION}

The work-integrated learning is an educational model that combines learning with work. It makes full use of different educational environment and resources inside and outside school, and integrates school education and off campus work that directly obtains practical experience, and runs through the training process of students [1]. The work-integrated learning and cooperation between school and enterprise conforms to the law of vocational education. It is a concrete embodiment and important way to combine education with productive labor and social practice. It reflects the essential characteristics

1. Tianjin Educational Science and Planning Project (VE3147).

2. Education Reform and Innovation Development Funds of Tianjin Agricultural University (20170202)

3. The major teaching Reform Tendering Project of Tianjin Agricultural University (2017-D-03) of vocational education and is beneficial to the growth of highquality skilled talents.

In recent years, the experts and scholars at home and abroad have done a lot of research on the work-integrated learning mode, and have made many research achievements, which is worth learning and using for reference [2-3]. However, the start of higher vocational education in China is relatively late, and it is not mature enough in the construction of work-integrated learning mode. In practice, there are many problems in the practice of developing the work-integrated learning model. These problems will seriously affect the quality of talent training in higher vocational colleges. Therefore, this paper analyzes the problems existing in the process of training and training, and puts forward some relevant improvement measures to improve the quality of training of talents.

\section{Problems IN The Process of Work-INTEgRATED LEARNING}

At present, under the background of developing vocational education vigorously, higher vocational colleges are able to explore the work-integrated learning mode based on their own characteristics and following the rules of vocational education development. Although significant achievements have been made and accumulated some valuable experience, problems have been exposed in the development process, for example, the development is still very uneven [4-5], and there are many urgent problems to solve.

\section{A. Exiting the Deviation in Educational Ideas}

In recent years, the scale of higher vocational education has expanded rapidly, but the reform of talent training mode has not been followed up in time, and it is basically the compression type of undergraduate. Most of the teachers lack 
the production practice in higher vocational colleges. Under the influence of traditional higher education, the curriculum system and teaching content overemphasize the systematicness of the theory. Teachers are used to the teaching methods of chalk and blackboard. Students are accustomed to listening and learning theory [6]. Such a talent training mode of school centered and classroom centered is unsuitable to the cultivation of practical ability and professional quality. It will seriously affect the quality and characteristics of higher vocational talents training, and further affect the survival and development of higher vocational education

\section{B. Disjunction Between Working and Learning}

The disconnection between higher vocational education and the actual production of enterprises has become the main reason for the increasingly prominent contradiction between the demand of graduates in higher vocational education and the needs of enterprises. It is manifested in the fact that the content of students' learning in school is out of touch with the actual work of the off campus business, or the work done by students in practical training is not related to their major. If students can understand, participate in practical training and enterprise production practice activities; students' enthusiasm and creativity will be very high. Therefore, the competitiveness of the students is strong when they are employed, the role changes smoothly after employment, and the adaptability and stability of the job are good. If students do not have a certain period of practice training and participate in the production practice, after graduation, most of the students will not be able to meet the needs of employers. This directly affects the development of the individual and the enterprise, and causes the outstanding contradiction between the enterprise and the higher vocational graduates. The disconnection between higher vocational education and the actual production of enterprises has become the main reason for the increasingly prominent contradiction between the demand of graduates in Higher Vocational Education and the needs of enterprises. The reform and innovation of workintegrated learning mode is not only the need to train high quality, highly skilled talents, but also an effective way to solve the employment difficulties of higher vocational graduates [7]. It is the key and difficult point for the National Demonstration Higher Vocational Colleges to innovate the work-integrated learning mode of higher vocational talents training. Thus, higher vocational colleges educators must make great efforts to explore and practice.

\section{Imperfect Mechanism of Working and Learning}

In order to ensure the effectiveness and sustainable development of the work-integrated learning mode, higher vocational colleges must cooperate with enterprises to explore and perfect the system and operation mechanism of teaching management, quality assurance and monitoring to adapt to the work-integrated learning. The main problems of the current operating mechanism are:

(1) The imperfect training management organization is imperfect. The responsibilities and powers of the school and enterprise in the training arrangements, teachers' cooperation, and process monitoring and results assessment are still not clear enough.

(2) The training management system is not perfect, although many vocational colleges have formulated the corresponding training management system, but the system is generally wide, lacking pertinence and operability, which leads to practice training in a mere formality, and can not reach the purpose of work-integrated learning.

(3) Guide monitoring is not in place. The specific requirements and quantitative criteria of the training is not clear in many higher vocational colleges, seriously affecting the effect of work-integrated learning.

\section{Lack of Enthusiasm of Enterprise}

Enterprises play a vital role in the cooperation of school and enterprise, and the mobilization of its enthusiasm directly affects the quality of talent training. In the current cooperation of school and enterprise, the enthusiasm of enterprises in cooperation needs to be improved. It is difficult to fully implement he cooperation of school and enterprise and the work-integrated learning mode to train the talents. It is very complicated that the interests of the three parties, such as colleges, enterprises and students, are involved in all aspects of both colleges and enterprises. The colleges should solve the cooperative enterprise, reach the cooperation intention, and sign the cooperation agreement. The college actively organizes teachers, students to enterprises, and employs technical personnel with practical experience to colleges. Enterprises need to solve how to arrange practical activities of teachers and students, how to participate in educational reform, how to coordinate the relationship between talents and production management, and so on.

\section{Measures and Suggestion to Solve the Problems of WORK-INTEGRATED LEARNING}

For higher vocational colleges, all kinds of difficulties and problems encountered in the process of work-integrated learning, the following measures are taken in the following aspects in accordance with the requirements of the training mode of work-integrated learning.

\section{A. Establishing and perfecting the legal system of the work- integrated learning}

As the enterprise occupies an active position in the use of people, the initiative of the current school enterprise cooperation is in the enterprise. There has not been a strong win-win mechanism for the cooperation between schools and enterprises. Therefore, the government should have relevant systems in the macro - control policy to mobilize the enthusiasm of the enterprise.

The system should clarify the obligations and responsibilities of enterprises in vocational education, require enterprises to have vocational training or pre job training in employing system, and constantly improve the guarantee mechanism of school enterprise cooperation. The cooperation school and enterprise ought to be supported from the policy, the regulation and the manpower, the material resources, the 
financial resources. The system should further deepen the reform of personnel system in higher vocational colleges, form an open employment mechanism, and widely attract and encourage enterprises, institutions, engineers, managers and special skilled personnel to serve as part-time teachers in higher vocational colleges.

Due to lack of legal protection, enterprises will worry that the status and rights in the process of the cooperation of school and enterprise can not be effectively guaranteed, thus affecting the enthusiasm of enterprises to participate. Therefore, relevant laws, development standards and certificate system must be constantly strengthened and perfected, so as to ensure the legal status of the cooperation of school and enterprise and earnestly safeguard the rights and interests of enterprises.

\section{B. Establishing a Special Coordination Institution System}

The development of school-enterprise cooperation in higher vocational colleges is subject to the level of economic and educational development in the region, and in turn promotes the development of local economy and the prosperity of vocational education [8]. Therefore, in addition to perfecting the relevant policies and regulations, the government should also set up special coordination institutions to regulate, standardize and promote school-enterprise cooperation. Special government coordination agencies should act as promoters, coordinators and supervisors of schoolenterprise cooperation. The main functions of the specialized government coordination system are:

(1) The study of the laws and problems of the development of school enterprise cooperation can provide theoretical basis and practical guidance for the formulation of laws and regulations and preferential policies. The government should strengthen the management of school-enterprise cooperation, ensures the stability of cooperative relations in legal form, and coordinates the contradictions and problems in the process of school enterprise cooperation, and explores the innovation mode of school -enterprise cooperation.

(2) The government guides enterprises to participate in the cooperation between school and enterprise, and provides a platform for cooperation between higher vocational colleges and enterprises. Such as building a cooperation platform, organizing the school enterprise cooperation forum, and so on, and strive to create the cooperation mechanism of the sharing of school and enterprise resources, complementary advantages, mutual benefit and win-win situation.

(3) Supervision, evaluation and incentive. The government should supervise the implementation of the terms and conditions of agreement between the two sides, the cooperation attitude of the enterprises, the usage of the special funds, the progress of the school enterprise cooperation, and the authenticity of the materials reported. Meanwhile, the government should also organize experts to evaluate the results of school enterprise cooperation. According to the evaluation results, we should implement preferential policies and corresponding incentive policies for participating enterprises, and encourage enterprises to participate in the initiative.

\section{Building the System of Personnel Training Consortium of School and Enterprise}

In view of present situation of some enterprises only participate in the selection of personnel or rarely involved in personnel training, the government should be encouraged to establish a long-term, mature thinking of educational cooperation. The joint system of training and training of talents in enterprises and schools is formed.

Schools and enterprises should cultivate talents according to the research of the talent market, the current situation and trend of regional economic development and the needs of the national industrial policy. The school and enterprise's engineers and technicians jointly work out the talent training plan and syllabus, and select the teaching content around the professional ability and quality, and determine teaching methods and means. Students alternate in the practice of enterprise production and school learning. Through the twoway involvement of school and cooperative enterprises, the basic theory and knowledge school, the training and practice in the enterprise learning organically, realize enterprise "zero distance", "zero gap" theory and practice, graduates posts "zero transition", meet the talent demand of the enterprise, and improve the quality of school and occupation the students' educational level, to improve the students' professional quality and the school level. In the process of running a school, the enthusiasm of the capital investment and the integration of the qualification of the enterprise should be greatly mobilized.

The school and the enterprise jointly carry out the training of the employees in the enterprise. The system of education and training should be formed. According to the needs of enterprise product upgrading, technological transformation, schools and enterprises should work together to grasp the staff training; to solve the problems of the technology, management, production and labor, to form the interdependent community of interests.

\section{Promoting the Innovation of System and Mechanism}

In higher vocational colleges, the training of talents with integrated engineering should be put into practice. In addition to updating ideas and creating conditions, higher vocational colleges need to work hard to achieve institutional innovation in order to make the work integrated learning operation standardized, orderly, efficient and durable. In addition, the college also set up a special office for the school-enterprise cooperation and the management of foreign relations. For outside, the functions of the office are to contact and cooperate with the units, communicate information, sign agreements, close relations, and handle related affairs. For inside, the functions of the office are to contact the departments concerned and the teaching department to implement the cooperation projects and to solve the difficulties and problems in the process of cooperation. The combination of education, social services and foreign school enrollment, employment, teaching, scientific research, training, skills identification can improve the change of colleges demand on the market reaction 
ability and service ability, improve the quality of personnel training, promoting high quality and stable employment of graduates.

\section{E. Mobilizing the Enthusiasm of the Enterprise}

The school should offer the college and student information to the enterprise actively, understand the needs of the enterprise, and put forward the intention of cooperation. In the process of implementation, higher vocational colleges actively cooperate with enterprises to do a good job of organization and management, and try not to add other trouble to the enterprises. Higher vocational colleges should take the initiative to do well in the employment education and recommendation work for graduates, provide opportunities for enterprises to select excellent talents, and do knowledge training for employees. In the combination of work and engineering, the students can choose the enterprise of the internship, and accept the dual management and examination of the college and the enterprise. Colleges and enterprises work together to enhance students' professional skills and professional quality training, enhance their employment competitiveness and career development potential, so that they can get jobs and high-quality employment smoothly.

\section{CONCLUSIONS}

In short, the work-integrated learning needs support and cooperation from all aspects of society. It is a systematic project, which requires close cooperation, and cooperation between schools, enterprises and governments. The government needs to establish and improve a series of policies and regulations for promoting the sustainable development of the work-integrated learning and formulate corresponding management measures. At present, some vocational colleges have begun to implement the new mode of school-enterprise cooperation and work-integrated learning [9], such as "Science and Technology Park of Higher Vocational College", "Subway College" and "School Practice Company". These advanced modes of work-integrated learning can be adapted to local conditions and spread to all parts of the country. Through continuous research and practice of work-integrated learning, higher vocational colleges can really cultivate developmental, compound and innovative high-end skilled talents that meet the needs of the society.

\section{ACKNOWLEDGMENT}

This work was financially supported by Tianjin 13th FiveYears Educational Science and Planning Project (VE3147), the Education Reform and Innovation Development Funds of Tianjin Agricultural University (20170202), and the major teaching Reform Tendering Project of Tianjin Agricultural University(2017-D-03).

\section{REFERENCES}

[1] Zhuang Xiaozhong. Problems and countermeasure of school-enterprise combination in vocational college. Journal of Fujian Commercial College, 2008, 5:73-77. (In Chinese)

[2] Liu Liying. Study on the cultivation system of vocational development ability of higher vocational college Students under the mode of the combination of work-study[J]. China Adult Education. 2015, 14: 105106. (In Chinese)

[3] Liu Liying, Yang Renjie, Wang Suwen, et al. Exploring on the cultivating model of the combination of working and learning in higher vocational education [C]. International Coference on Social Science and Higher Educaion, 2017, 99:13-16.

[4] Jiang Fang, Xiao Qi. Problems and countermeasures of teaching manage ment in higher vocational colleges under the mode of work study combination[J]. Education and Vocation, 2015, 28: 25-27. (In Chinese)

[5] Zhao Baofang, Han Zhensheng, Wang Yan. Research on problems of practice teaching conditions under work-study combination talents training pattern in vocational colleges[J]. Higher Vocational EducationJournal of Tianjin Vocational Institute, 2010, 19(1): 30-32+48.(In Chinese)

[6] Zhang Liang. Problems existed in teaching management of higher vocational education under the model of working and learning combiantion and the countermeasutes [J]. Vocational and Technical Education, 2010, 31(11): 74-76. (In Chinese)

[7] Tan yongping. Improvement for course system of exploration technology and engineering based on specialized direction of alumni [J]. Higer Education Forum, 2016, 7: 79-82. (In Chinese)

[8] Liu Jixiu, Wang Xiumei. Study on the construction of teaching materials under the mode of combining work with study in higher vocational colleges[J]. Journal of Tianjin Academy of Education Science, 2009, (3): 67-68. (In Chinese)

[9] Yan Lili. Practice and Reflection on the training mode of workintegrated learning in Higher Vocational Colleges[J]. Education and Vocation, 2015, 1(30):83-85. (In Chinese) 